

\section{From Subsistence to Profit Transforming Smallholder Farms}

Shenggen Fan, Joanna Brzeska, Michiel Keyzer, and Alex Halsema 


\section{ABOUT IFPRI}

The International Food Policy Research Institute (IFPRI), established in 1975, provides research-based policy solutions to sustainably reduce poverty and end hunger and malnutrition. The Institute conducts research, communicates results, optimizes partnerships, and builds capacity to ensure sustainable food production, promote healthy food systems, improve markets and trade, transform agriculture, build resilience, and strengthen institutions and governance. Gender is considered in all of the Institute's work. IFPRI collaborates with partners around the world, including development implementers, public institutions, the private sector, and farmers' organizations. IFPRI is a member of the CGIAR Consortium.

Copyright (C2013 International Food Policy Research Institute. All rights reserved. Contact ifpri-copyright@cgiar.org for permission to reprint. This food policy report has been peer reviewed.

Design David Popham

Cover photo (C) 2008 G. M. B. Akash/Panos

DOI http://dx.doi.org/10.2499/9780896295582

ISBN 13-digit 978-0-89629-558-2 


\section{CONTENTS}

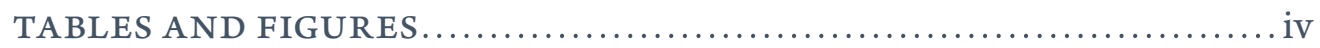

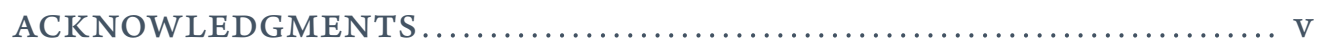

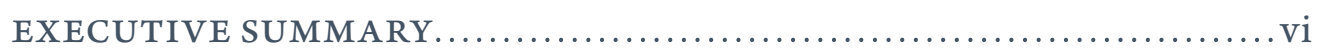

Is Small Still Beautiful? ..............................................

Emerging Challenges Facing Smallholders .................................. 6

Policy Options to Strengthen Smallholder Farmers with Agricultural Potential .................................. 11

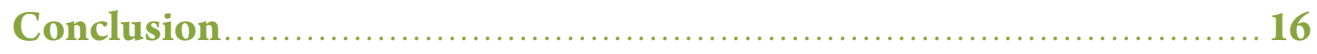

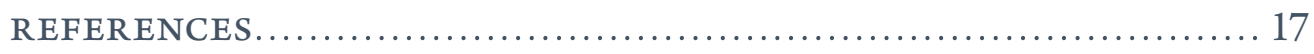

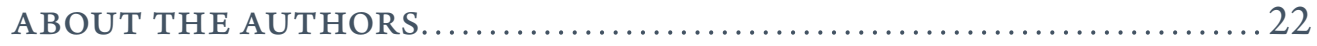




\section{TABLES AND FIGURES}

TABLES

1 Typology of smallholder farms and appropriate strategies and interventions ............ 4

FIGURES

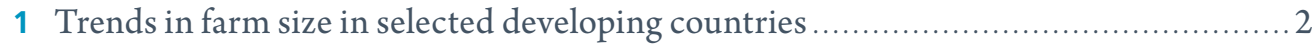

2 Expected impact of drought and floods on Malawian farmers' annual earnings ..........8

3 Agricultural investment needs, investment flows, and the financing gap in developing

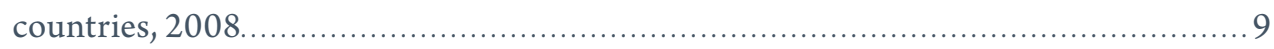

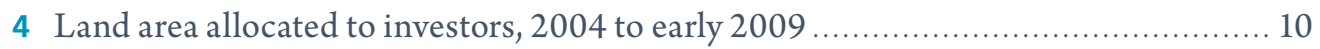




\section{ACKNOWLEDGMENTS}

We thank Tolulope Olofinbiyi, Rajul Pandya-Lorch, Alexander Stein, and Klaus von Grebmer for their excellent advice and suggestions at various stages of the process. We also appreciate the thoughtful and detailed comments provided by IFPRI's Publications Review Committee and two anonymous reviewers as part of the IFPRI peer-review process. 


\section{EXECUTIVE SUMMARY}

$\mathrm{T}$ his food policy report presents a typology of the diverse livelihood strategies and development pathways for smallholder farmers in developing countries, and offers policy recommendations to help potentially profitable smallholders meet emerging risks and challenges.

\section{MAIN FINDINGS}

Smallholder farmers in developing countries play a key role in meeting the future food demands of a growing and increasingly rich and urbanized population. However, smallholders are not a homogeneous group that should be supported at all costs. Whereas some smallholder farmers have the potential to undertake profitable commercial activities in the agricultural sector, others should be supported in exiting agriculture and seeking nonfarm employment opportunities.

For smallholder farmers with profit potential, their ability to be successful is hampered by such challenges as climate change, price shocks, limited financing options, and inadequate access to healthy and nutritious food. By overcoming these challenges, smallholders can move from subsistence to commercially oriented agricultural systems, increase their profits, and operate at an efficient scale-thereby helping to do their part in feeding the world's hungry.

\section{POLICY IMPLICATIONS}

Such achievements are possible only in a policy and investment environment that

- promotes context-specific farm size,

- supports productive social safety nets,

- improves risk-mitigation and adaptation strategies,

- links agriculture, nutrition, and health,

- promotes pro-smallholder value chains, and

- increases smallholder-friendly financing and investment.

All of these measures, adapted to each country's stage of economic development and transformation, will play a critical role in bringing down the barriers to profitable and scaleefficient agricultural operations by smallholders. 


\section{Is Small Still Beautiful?}

N THE COMING DECADES, WORLD AGRICULTURE WILL NEED TO UNDERGO MAJOR CHANGES to meet the future food demands of a growing and increasingly rich and urbanized population. Smallholders in developing countries play a key role worldwide in this food security equation. They supply a large share of global agricultural output and are among the poorest and most foodinsecure people in the world. However, smallholders are not a homogeneous group but rather a diverse set of households with varying farm and household characteristics. Smallholder farm systems are also not a permanent phenomenon that should be maintained at all costs. Whereas some smallholders have the potential to shift from subsistence farming to commercially oriented and profitable farming systems, others have more opportunities to improve their livelihood strategies outside of the agricultural sector.

Traditionally, literature on smallholders has focused on challenges to their livelihood strategies, such as lack of human capital and limited access to infrastructure, markets, and technologies. But smallholders have also become increasingly vulnerable to a spectrum of emerging climatic, health, price, and financial risks and challenges. Not only does the occurrence of these shocks endanger already fragile food production systems, but the mere likelihood of their occurrence makes some smallholders more risk adverse and more likely to pursue more subsistenceoriented activities, thus causing smallholder poverty to persist (Dercon 2009).

In the face of these emerging challenges, smallholder farmers who have the potential to become profitable need access to the right set of productivity-enhancing tools, such as technology and capital, to become profitable and resilient participants within the agricultural sector. At the same time, conditions should be created for other smallholders to exit agriculture either altogether or as their primary activity, so that the remaining efficient smallholders can increase the size of their operational holdings.

This report presents a typology of the diverse livelihood strategies and development pathways for smallholder farmers, followed by a discussion of the emerging risks and challenges facing smallholders. It concludes with policy recommendations that focus on interventions for potentially profitable smallholder farms.

\section{THE IMPORTANT BUT SHIFTING ROLE OF SMALLHOLDERS}

Thinking about the role of smallholders has evolved over time, and this role is increasingly being seen in a broader economic context. The discussion about smallholder farms should be expanded beyond a strict focus on small versus 
large farms to reflect the idea that optimal farm size is a dynamic concept that changes as a country's overall economy grows and as nonagricultural sectors develop. Within this framework, interventions must be tailored to the different types of smallholder farms and the specific contexts in which they operate.

The backdrop to the debate on small versus large farms is the dominance of smallholder farming systems in the developing world. Worldwide about half a billion farms are smaller than 2 hectares, and these farms are getting smaller in many countries (Figure 1) (Hazell et al. 2007). The continuing decline is due to factors such as growing rural population, urban growth that is not labor intensive, formal and informal barriers to rural-urban migration, and distortionary land policies. Small farms are estimated to produce fourfifths of the developing world's food (FAO 2011). Moreover, they are home to approximately two-thirds of the world's 3 billion rural residents, the majority of people living in absolute poverty, and half of the world's undernourished people (IFPRI 2005).

To get a better understanding of the role that smallholders play in a country's development, it is important to first look at the broader context of agricultural development. Growth in agriculture has been shown to be an important part of the initial stage of transformation in many countries.
Agricultural growth can provide the economy with muchneeded stimuli such as capital, labor, and foreign exchange to finance and fuel growth in nonagricultural sectors (see, for example, de Janvry and Sadoulet 2009). The connection is not automatic, however, and varies according to countryspecific circumstances, especially the country's potential for agricultural and nonagricultural (including minerals and manufacturing) sources of growth (Hazell et al. 2010). Past successes in promoting agricultural development, such as the Green Revolution in Asia, were grounded in interventions and reforms that supported equitable agricultural growth and were led by small farms (Hazell 2009). Policies that enabled smallholder participation in the Green Revolution included the equitable distribution of land and secure ownership and tenancy rights, alongside scale-neutral technologies, temporary input subsidies, and large investments in infrastructure (such as roads and irrigation).

A large body of empirical research argues that there are efficiency benefits to small farms. Studies have shown a strong inverse relationship between farm size and land productivity, with smaller farms generating higher per-unit farm output than larger farms (for a summary, see Heltberg 1998). The standard explanations for this inverse relationship focus on small farms' more intensive use of inputs and the lower costs associated with supervising family labor

\section{FIGURE 1 Trends in farm size in selected developing countries}

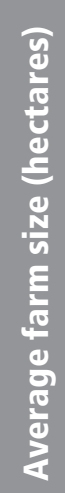

8
7
6
5
4
3
2

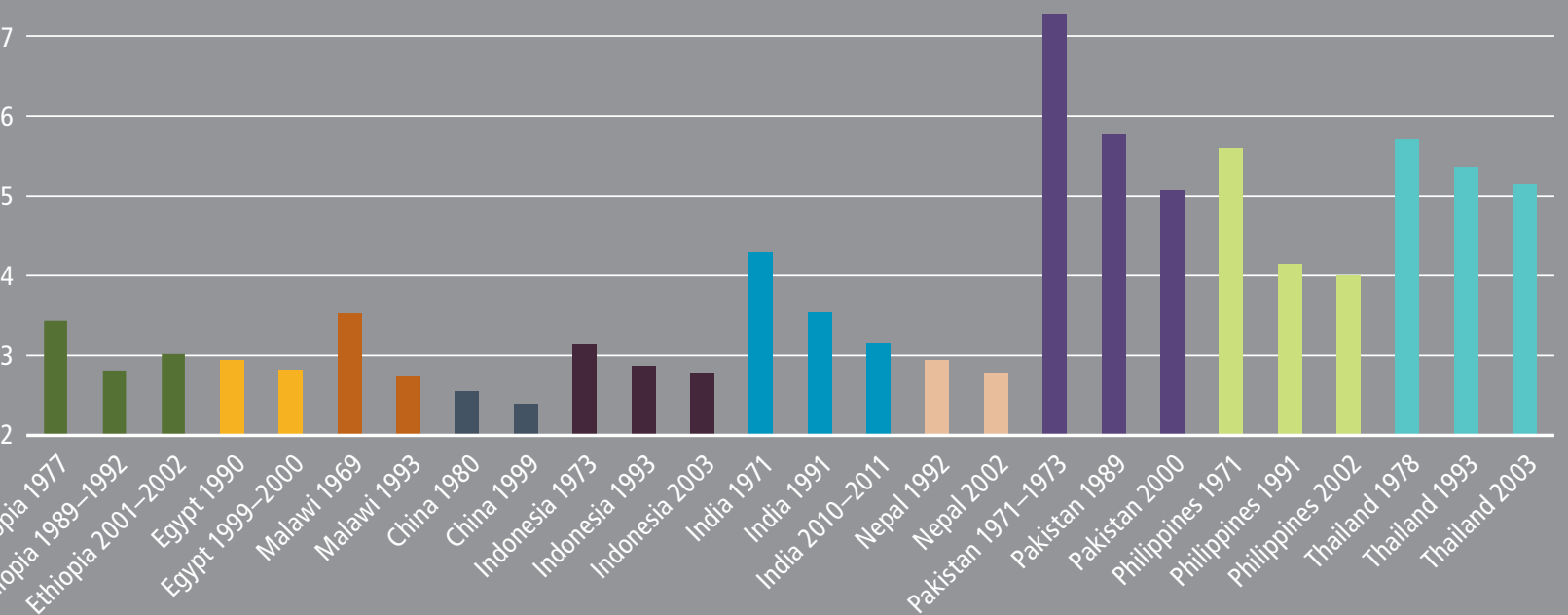

Source: FAO (2000, 2010); Fan and Chan-Kang (2003). 
on small farms compared with hired labor on larger farms. Multiple studies, however, have called into question the absolute efficiency advantage of small farms (Helfand and Levine 2004; Barrett, Bellemare, and Hou 2010). These researchers have argued that larger commercial farms have an advantage in terms of finance, technology, and logistics and that the inverse relationship disappears above a certain farm size or after factors such as land quality are taken into account-but even these studies have been challenged. A more dynamic argument on efficient farm size is that small farms have an advantage over large farms in terms of labor supervision and local knowledge, but larger farms gain the advantage as an economy shifts toward technologically advanced, capital-intensive, and market-oriented agriculture (Poulton, Dorward, and Kydd 2010).

One of the fundamental models of development economics asserts that the development of a dual-sector economy occurs through the transfer of low-productivity agricultural labor to the higher-productivity industrial and service sectors. The flow of labor continues until the marginal productivity of labor-in other words, income-is equal between the farm and nonfarm sectors, after adjusting for labor quality and cost of living. This essentially means that workers will move from one sector to the other until wages are equal in the two sectors. Within this framework, farm size is an endogenous variable whose optimal value is the point of equal marginal productivity (again, income). Generally, it is expected that as laborers migrate out of rural areas, operational farm size will increase as those leaving agriculture sell or rent their land to the remaining farmers who can more efficiently expand their operations.

Yet, over the past several decades, farm structures in many developing countries have been affected by government policies that distort incentives for, and limit the extent of, efficiency-enhancing land transactions (this is not to deny any justification for equity-oriented redistributive land reforms in certain highly unequal socioeconomic contexts). Such interventions have included the imposition of ceilings on landholding size in a number of Asian countries, such as Bangladesh, India, Pakistan, and the Philippines. Alternatively, many land-abundant developing countries, especially in Africa south of the Sahara, have artificially promoted large-scale, commercial farms. These countries include post-independence Nigeria, Sudan, and Tanzania, as well as the Democratic Republic of Congo and
Mozambique, where more recent large land acquisition deals have taken place.

This artificial promotion of small or large farms through restrictions on minimum or maximum landownership or rental has been shown to result in inefficiencies by reducing farm productivity. For example, preliminary findings from the Philippines show that imposing a ceiling on farm size results in the misallocation of resources, causing agricultural labor productivity to drop by 7 percent and the share of employment in agriculture to increase from 45.1 to 48.5 percent (Adamopoulos and Restuccia 2013). The same can be seen in India and China, where reduced restrictions on land rental markets improved agricultural productivity by transferring land to more efficient (but often still poor) producers (Deininger and Jin 2005; Deininger, Jin, and Nagarajan 2008). In fact, evidence from China shows that removing constraints on land rental markets has a much more positive impact on productivity gains and rental market participation than does administratively reallocating land because the latter is weighed down by high transaction costs and imperfect information.

\section{TYPOLOGY OF DEVELOPMENT PATHWAYS FOR SMALLHOLDERS}

Given the pivotal and substantial presence of smallholders in many developing countries, policies that directly or indirectly affect smallholder farmers have significant effects on the social and economic trajectory of those countries. However, the appropriate livelihood strategies should not be treated as a single and unique pathway but instead as a dynamic process that reflects the different types of smallholders and economies (Table 1). We have created a typology that reflects the diversity of possible livelihood strategies and development pathways for smallholder farmers. This typology distinguishes between (1) the profitability of smallholders within the agricultural sector (subsistence farmers without profit potential, subsistence farmers with profit potential, and commercialized smallholder farmers) and (2) the different stages of economic transformation (agriculture-based, transforming, and transformed economies).

First, smallholders are a diverse set of households and individuals who face various constraints on their ability to undertake potentially profitable activities in the agricultural sector. Past studies have divided smallholders based on 


\section{TABLE 1 Typology of smallholder farms and appropriate strategies and interventions}

\begin{tabular}{|c|c|c|c|c|}
\hline \multirow{2}{*}{$\begin{array}{l}\text { TYPE OF } \\
\text { FARM }\end{array}$} & \multirow{2}{*}{ CHARACTERISTICS } & \multicolumn{3}{|c|}{ STRATEGIES } \\
\hline & & Agriculture-based & Transforming & Transformed \\
\hline 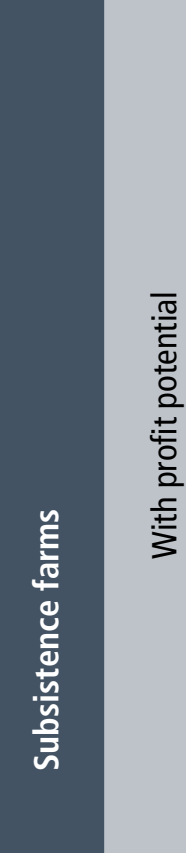 & $\begin{array}{l}\text { Soft constraints to land size } \\
\text { and agricultural production } \\
\text { - Limited access to markets } \\
\text { and information } \\
\text { - Limited financial capital } \\
\text { - Limited access to } \\
\text { infrastructure } \\
\text { - Limited access to } \\
\text { smallholder friendly } \\
\text { technologies }\end{array}$ & $\begin{array}{l}\text { - Productive social safety } \\
\text { nets } \\
\text { - Investment in infrastruc- } \\
\text { ture, agricultural research } \\
\text { and extension, and small- } \\
\text { holder-friendly and cli- } \\
\text { mate-smart technologies } \\
\text { - Access to innovative } \\
\text { financial services }\end{array}$ & $\begin{array}{l}\text { - Flexible arrangements for } \\
\text { land transfer } \\
\text { - Risk reduction and man- } \\
\text { agement tools } \\
\text { - Access to market infor- } \\
\text { mation (e.g., ICTs) } \\
\text { - Pro-smallholder, nutri- } \\
\text { tion-sensitive value } \\
\text { chains } \\
\text { - Social safety nets and } \\
\text { improved access to } \\
\text { housing, education, and } \\
\text { health services for rural } \\
\text { migrants } \\
\text { - Vertical and horizontal } \\
\text { coordination to meet } \\
\text { safety, quality, and quan- } \\
\text { tity standards } \\
\text { - Enhanced role of farmers' } \\
\text { organizations, particularly } \\
\text { for women farmers }\end{array}$ & $\begin{array}{l}\text { - High-value production } \\
\text { - Reduced trade restric- } \\
\text { tions and subsidies } \\
\text { - Flexible arrangements for } \\
\text { land transfer } \\
\text { - Efficiency- and quality- } \\
\text { enhanced production } \\
\text { systems } \\
\text { - Vertical and horizontal } \\
\text { coordination to meet } \\
\text { safety, quality, and quan- } \\
\text { tity standards }\end{array}$ \\
\hline 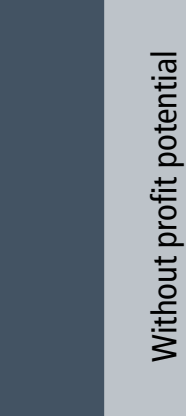 & $\begin{array}{l}\text { Soft constraints plus hard } \\
\text { constraints to land size and } \\
\text { agricultural production } \\
\text { - High population density } \\
\text { - Low quality soil } \\
\text { - Low rainfall and high } \\
\text { temperatures } \\
\text { - Remote location }\end{array}$ & $\begin{array}{l}\text { - Social safety nets } \\
\text { - Nutrition-focused crop } \\
\text { production for own } \\
\text { consumption } \\
\text { - Education and training } \\
\text { for nonfarm employment } \\
\text { - Migration to urban cen- } \\
\text { ters and other agriculture } \\
\text { areas with greater profit } \\
\text { potential }\end{array}$ & $\begin{array}{l}\text { - Social safety nets } \\
\text { - Improved access to housing } \\
\text { viced for rural migrants } \\
\text { - Education and training for } \\
\text { - Flexible arrangements for I }\end{array}$ & $\begin{array}{l}\text { education, and health ser- } \\
\text { onfarm employment } \\
\text { nd transfer }\end{array}$ \\
\hline 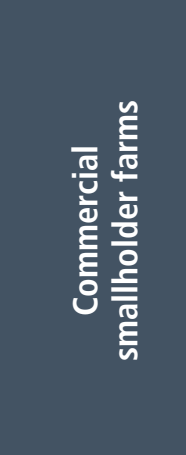 & $\begin{array}{l}\text { - Soft-constraints } \\
\text { - Limited access to capital, } \\
\text { insurance, and other risk } \\
\text { reduction tools }\end{array}$ & $\begin{array}{l}\text { - Vertical and horizontal } \\
\text { market coordination to } \\
\text { meet safety, quality, and } \\
\text { quantity standards } \\
\text { - Smallholder-focused, } \\
\text { climate-smart, and } \\
\text { nutrition-enhancing } \\
\text { technologies } \\
\text { - Investment in infrastruc- } \\
\text { ture, agricultural R\&D, } \\
\text { and extension }\end{array}$ & $\begin{array}{l}\text { - High-value and nutrition } \\
\text { sensitive food chains } \\
\text { - Flexible arrangements for } \\
\text { land transfer } \\
\text { - Links to urban and global } \\
\text { markets } \\
\text { - Vertical and horizontal } \\
\text { market coordination } \\
\text { - Enhanced role of farmers' } \\
\text { organizations, particularly } \\
\text { for women farmers }\end{array}$ & $\begin{array}{l}\text { - High-value crops } \\
\text { - Flexible arrangements for } \\
\text { land transfer } \\
\text { - Clear regulatory frame- } \\
\text { works and intellec- } \\
\text { tual property rights to } \\
\text { link private sector with } \\
\text { smallholders }\end{array}$ \\
\hline
\end{tabular}

Source: Authors' compilation. 
socioeconomic and biophysical variables such as population density, agricultural potential (determined by agroecological conditions such as water supply, soil fertility, and biotic pressures from pests and diseases), and market access (Omamo et al. 2006). Other determinants of smallholder livelihood strategies include the asset position of households and the characteristics of the production environment (including institutions, power structures, and market policies).

Within this typology, subsistence farmers are smallholders who consume the majority of their farm output and who are held back from participating more actively in commercially oriented agriculture by a variety of constraints. The potential to turn production systems into profitable enterprises is greatest among the subsistence farmers who are facing soft constraints_-such as limited financial and human capital and asymmetric access to markets and information - that can be addressed through various policy and programmatic channels. In addition to soft constraints, the presence of hard constraints - such as marginal lands that are far from markets, are limited in size, and have extremely low rainfall and soil quality - severely hampers the ability of other smallholders to increase their production capacity and move toward profitable farming systems. Commercial smallholders are already involved in profitable agricultural activities but are held back from scaling up their commercial activities by factors such as limited access to capital and risk-reducing tools.

Second, the appropriate development pathway for smallholder farmers also depends on the level of transformation within the country's economy. The transformation process involves increased productivity and commercialization in agriculture alongside economic diversification and growth. The exact duration and character of the transformation varies across developing countries, but it includes several fundamental changes in the structure of the economy: a declining share of agriculture in gross domestic product (GDP) and employment, increasing rural-to-urban migration, the rise of a modern industrial and service economy, and a demographic transition to lower birth and death rates (Timmer 1988). In the typology, agriculture-based economies are those that derive a significant portion of their economic output and growth from the agricultural sector. This group includes most countries in Africa south of the Sahara. Transforming economies, which lie mainly in East and South Asia, are those in which agriculture's significant role is being gradually replaced by the manufacturing and service sectors, although poverty continues to be heavily concentrated in rural areas. Finally, transformed countries, which are mainly in Eastern Europe and Latin America, are those in which agriculture has become a minor source of economic growth. 


\section{Emerging Challenges Facing Smallholders}

\section{A \\ LARGE BODY OF LITERATURE HAS TRADITIONALLY ANALYZED SMALLHOLDERS' PRODUC- tive capacity in the face of several interrelated socioeconomic challenges (Hazell et al. 2007; World Bank 2008). These challenges include insufficient access to markets, infrastructure, and technology; high marketing and transport costs; and limited resources (land and human capital). While these traditional challenges persist, increasingly complex natural and human- caused shocks are making smallholders more vulnerable.}

Smallholders often have limited access to markets for both inputs and outputs, and this has a significant effect on their production activities. In part, the geographic dispersion and limited access to infrastructure (including transportation networks and market facilities) in many rural areas drive up transaction costs, lower smallholders' profit margins, and lead many smallholders to pursue more subsistence-oriented production practices. Similarly, smallholders' limited access to productivity-enhancing technologies is grounded in an environment where national research systems do not sufficiently prioritize smallholder-friendly technologies and extension systems fail to help smallholders gain access to and adopt such technologies. Distorted land tenure structures-including insecure property rights and underdeveloped land rental and sales marketshave been linked with less efficient land use and lower productivity-enhancing investments. Smallholders' productivity is also affected by lack of access to education, which could help build the skills needed to manage on- and offfarm production systems more efficiently and raise smallholder adoption of innovative and high-return technologies.
Smallholders have become increasingly vulnerable to a spectrum of emerging climatic, health, price, and financial risks and challenges as well. These emerging challenges lead many smallholder farmers to pursue livelihood strategies that involve lower-risk and lower-yielding agricultural activities. Such responses can help smallholders cope with adverse events, but they also cause poverty to persist, trapping smallholders in a cycle of little or no profits, with limited opportunities to undertake more productive and innovative activities.

\section{FOOD PRICE VULNERABILITY}

The recent food price crisis is by definition associated with adverse welfare effects, but the increase in food prices also generated potential opportunities for smallholder farmers in developing countries by creating incentives for them to increase production and profits. The magnitude and direction of the impact of price volatility on smallholder farmers depend on a number of variables. These include the concurrent increase in production and consumption costs, whether the farmers are net buyers or sellers of food, and 
the capacity of smallholders to step up their production and to bring the increased output to market (making use of storage and transport). Evidence from Ghana shows that higher maize prices have the largest adverse welfare effects on urban, female-headed, poor, and small farm households because these groups are traditionally net buyers of maize (Minot and Dewina 2013). Similarly, recent studies in Bangladesh and Malawi show that an increase in the price of staple crops - rice and maize, respectively — results in a higher welfare loss for small landholders compared with larger landholders (Karfakis et al. 2011). The impact of price fluctuations also depends on other household characteristics, including off-farm income and the income linkages between buyers and sellers (Aksoy and IsikDikmelik 2011).

At the same time, an analysis of household data from before and after the 2007-2008 food price crisis in Indonesia shows that the crisis created "forward-looking incentives" for farmers to increase investments in productive assets (Nose and Yamauchi 2012). Rising food prices translated into higher investments by both large and small farmers, with higher prices and the resulting higher incomes partly relieving credit constraints among smallholders. These findings also reveal, however, that unanticipated price shocks had a smaller positive impact than anticipated shocks. This means that although some smallholder farmers with marketable surplus stand to profit from rising food prices, the volatility and uncertainty of prices make it difficult for them to take advantage of these opportunities. The uncertainty concerning future food prices raises questions about smallholders' future income and risks as both producers and consumers.

\section{NUTRITION AND HEALTH}

Agriculture, nutrition, and health are closely linked, and smallholders play an important role in this relationship (as both consumers and producers). Shocks to the health and nutritional status of smallholder farm households have been shown to reduce these households' ability to undertake more productive and innovative activities that generate food and income (for an overview, see Fan and PandyaLorch 2012). This is largely because such shocks lead to losses in physical and financial assets and work capacity and skills. Nutrition has a particularly significant influence on the relationship between health and agricultural productivity. Nutritional deficiencies-especially in terms of micronutrient intake-impair farmers' productivity through poor physical health, inability to innovate, and poor cognitive development (Ulimwengu et al. 2011). Health shocks and the subsequent loss of agricultural production capacity can also lead to changes in cropping patterns and diminishing crop diversity. Affected households may switch to less labor-intensive crops-such as root crops - that also often have lower yields, lower economic value, and lower nutritional value, starting a vicious circle of ill health, poor nutrition, and low productivity (Barnett and Rugalema 2001; UN 2004). Development efforts over the past several decades have focused on providing an adequate supply of food through improved agricultural productivity, but they have failed to deliver adequate quantities of nutritionally balanced food, especially to poor people. For example, strategies to increase food production during the Green Revolution were disproportionately concentrated on productive cereals at the expense of more nutrition-dense crops and placed little focus on increasing nutrient intake and human health (Welch and Graham 1999).

As developing countries' populations grow larger, richer, and more urban, the intensification of agricultural production will occur in rapidly changing agrifood value chains (Reardon et al. 2009). Increasingly globalized and liberalized agrifood markets are dominated by supermarkets, distributors, processors, and agro-exporters that are introducing and expanding food safety and quality standards that many smallholders are unable to meet. These developments are further shifting the competitive advantage away from smallholder farmers toward large-scale producers. At the same time, more intensive agricultural practices will have significant implications for food safety, disease transmission, and environmental sustainability. In fact, the presence of contaminated food in the food distribution chains and the transmission of zoonotic diseases, such as avian influenza, is already an emerging public health concern in many developing countries. In China, for example, the contamination of milk and baby formula, which sickened an estimated 300,000 people, has been linked to the rapid and unregulated development of the dairy sector (Pei et al. 2011).

\section{CLIMATE CHANGE}

Climate change is likely to increase the vulnerability of many poor rural communities. Given their already weak 
resource base, smallholder farmers are especially sensitive to rising temperatures, changing precipitation patterns, increasing risk of crop pests and diseases, and more frequent extreme weather events - all of which can raise the incidence of crop failure and harm livelihoods. Climate change is likely to aggravate existing nonclimatic stress factors for smallholders, such as marginal land use and limited access to technical knowledge, insurance, and financial services. Projections of the potential impact of climate change point to further threats to already strained global food production systems, with the yield of major smallholder crops - such as wheat, maize, and rice - predicted to decrease in many areas (Lobell, Schlenker, and Costa-Roberts 2011; Nelson et al. 2010). Moreover, results from model simulations show that climate change-induced losses in agricultural productivity are largest in developing countries, with losses forecast to reach 10-20 percent throughout Africa, Southeast Asia, and South Asia, regions where smallholder populations are relatively large (Wheeler 2011).

Extreme natural events-such as droughts, wildfires, heat waves, and floods - have the capacity to threaten the already fragile livelihoods of smallholders. Evidence from Malawi shows that small-scale farmers suffer greater drought- and flood-induced economic losses than mediumand large-scale farmers (Figure 2) (Pauw, Thurlow, and van Seventer 2010). For example, small-scale farmers are more likely to produce drought-sensitive maize while medium- and large-scale farmers grow more droughtresistant tobacco. This difference in cropping patterns means that smallholders experience greater economic losses during droughts. Similarly, findings from Mexico reveal that smallholder and subsistence farmers are more likely than larger-scale farmers to live in areas where agriculture is highly vulnerable to climate change and where the largest increase in vulnerability will occur in the coming decades (Borja-Vega and de la Fuente 2013). In other words, smallholders are more likely to experience climatic extremes that will add stress and uncertainty to their production systems, and these smallholders have less adaptive capacity and are more sensitive to these changes.

In recent years, several consecutive poor rainy seasons led to a severe drought in large parts of the Horn of Africa, resulting in crop and livestock losses alongside lower yields in crop and livestock production among the region's smallholder farmers and pastoralist communities. As a result, many of the region's smallholder farmers and pastoralists have become more food insecure and cash strapped. In Ethiopia, for example, where a significant fraction of the rural population consists of semi-nomadic herders or pastoralists, drought has had devastating impacts on the rural poor. A changing climate has the potential to magnify the vulnerability of global food systems by increasing the occurrence of unpredictable and extreme weather as well as generating a rise in sea levels, thereby posing progressively more complex and frequent challenges to food producers and consumers alike.
FIGURE 2 Expected impact of drought and floods on Malawian farmers' annual earnings

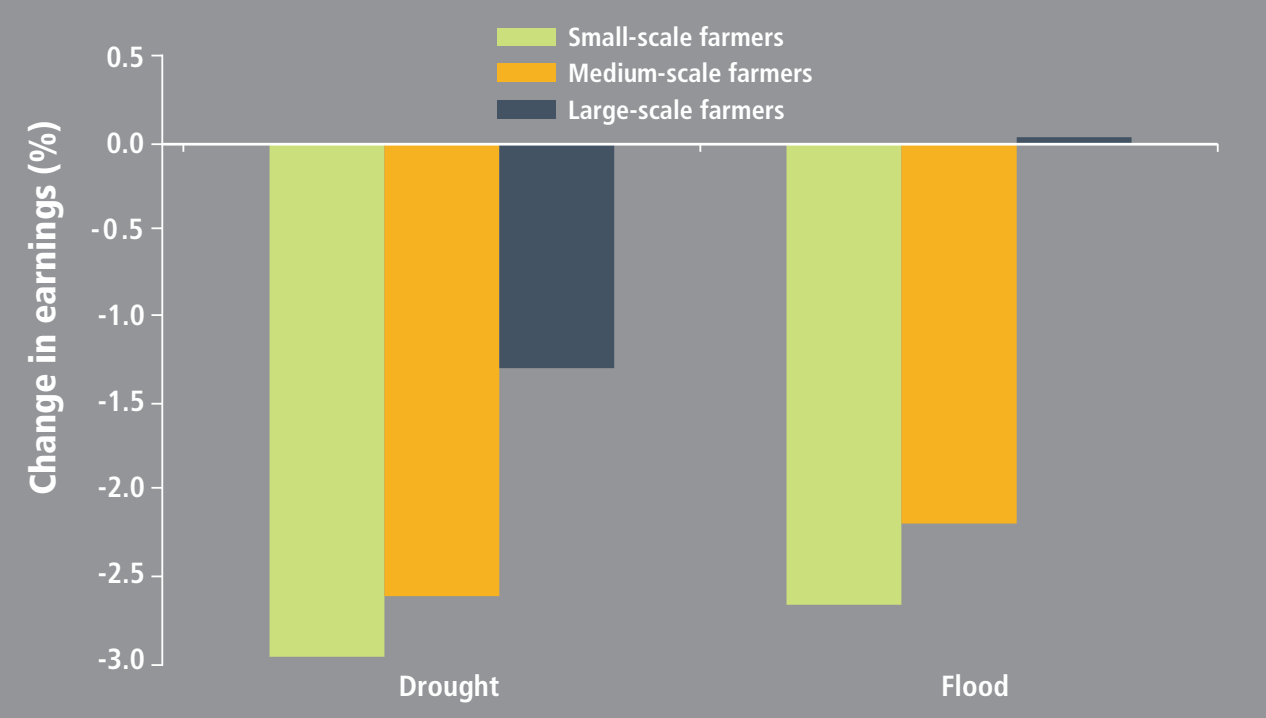

Source: Authors, based on data from Pauw, Thurlow, and van Seventer (2010). 


\section{FIGURE 3 Agricultural investment needs, investment flows, and the financing gap in developing countries, 2008}

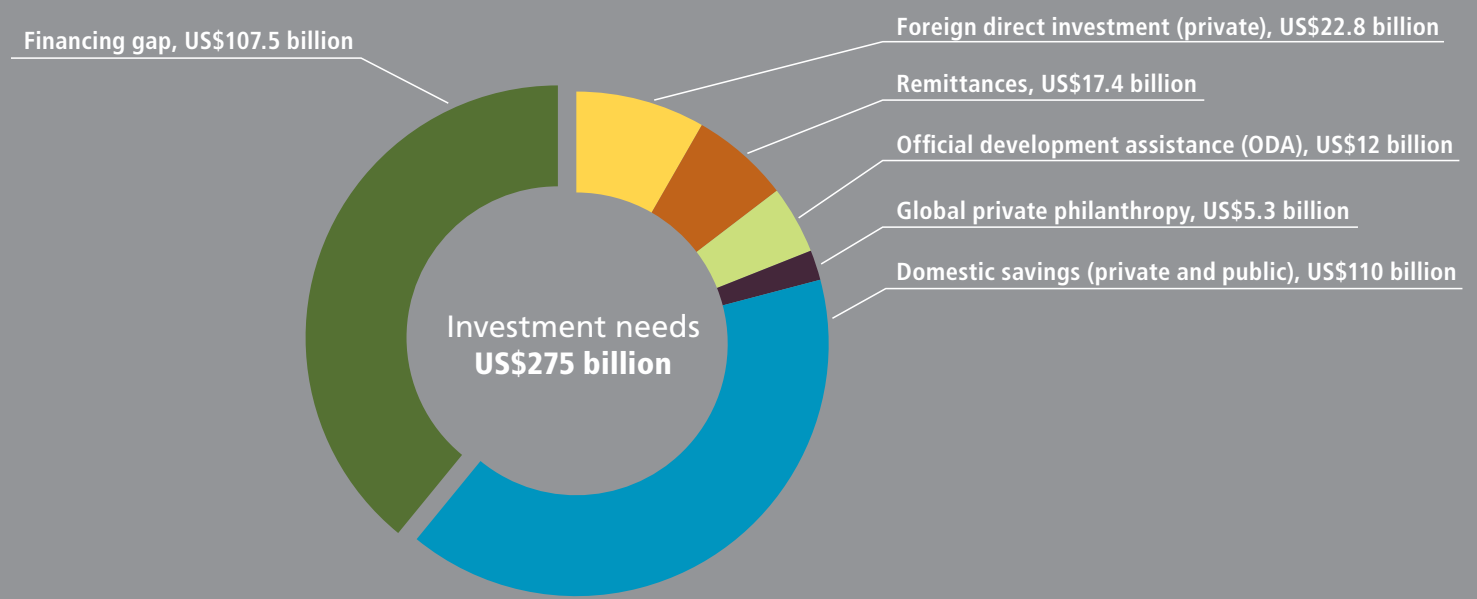

Source: Authors, based on data from Motes (2011) and Center for Global Prosperity-Hudson Institute (2011).

Note: These data do not include investment in infrastructure.

\section{LIMITED ACCESS TO FINANCE AND CAPITAL}

Current capital flows to the agricultural sector as a whole remain grossly insufficient in the face of upcoming agricultural demand (Figure 3).

Many smallholders are excluded from productivityenhancing financial services and are unable to secure much-needed fixed and working capital, which ranges from land and buildings to machinery, high-yielding seeds, and fertilizer. One of the major financing challenges facing smallholders is their limited access to financial options and services for keeping their savings in formal accounts. The absence of financial savings services contributes to the low savings rate among smallholders and their lack of buffers against adversity and shocks. China and other countries in Asia record higher savings rates than Africa. For example, the savings rate of the rural poor is $20-30$ percent in China (Horioka and Wan 2007; Dewen 2010), compared with 3 percent in Nigeria (Obayelu 2012). Savings are also frequently invested in social capital (weddings and funerals) to secure participation in the local community and to help cope with adversities such as accidents or illness at the individual level, but this approach loses its effectiveness when the whole community is affected. A survey among Ghanaian cocoa farmers showed that median spending on funerals equaled the median savings (Hainmueller, Hiscox, and Tampe 2011). On average, more was spent on funerals than on tertiary education, vaccination or other medical expenses, home improvements or construction, and rent combined. The indirect cost of funerals may be even higher because they divert time away from labor-an average funeral takes three days, and all villagers are expected to come.

Another challenge to smallholder financing is the limited number of loans from commercial banks to agriculture and the rural poor in many developing countries: for example, only a quarter of agricultural loans in Africa south of the Sahara originated from a bank (Banerjee and Duflo 2007). Reasons for this situation include the dispersed demand and high cost of service in low-population areas; the weak administrative capacity of rural banks; agriculturespecific covariate risks such as variable weather patterns, pests, and price fluctuations; and lack of formally defined property and land-use rights to act as collateral for loans. In recent years, the financial crisis has forced the banksupervising authorities in many countries to raise reserve requirements, making it even more difficult for small farmers to secure loans.

Over the past several decades, microfinance designed to improve rural smallholders' access to credit has gained prominence as a poverty-reduction tool, but the reality has been mixed (Bateman 2011). The small size and short maturity of microcredit loans do not adequately address the seasonality of smallholders' production and income 
cycles or their long-term needs for more productive capital investments, such as machinery and storage facilities. Further, microcredit schemes are often incompatible with high covariate risks (including droughts and floods that affect whole communities) and the high transaction costs of delivering services to small-scale and geographically dispersed farmers. This situation forces some smallholders to turn to informal moneylenders (who charge even higher interest rates) for short-term loans to cover their unsustainable microfinance debt. Microfinance loan delinquency in Bosnia and Herzegovina, Morocco, Nicaragua, and Pakistan has been linked to borrowing from multiple geographically concentrated microcredit institutions, overstretched microfinance capacity, and a loss of microfinance credit discipline (Chen, Rasmussen, and Reille 2010; Schicks and Rosenberg 2011).

Foreign direct investment (FDI) offers another way to bridge the investment gap in agriculture, but challenges remain on how to link it better to smallholders and maximize smallholder benefits. Currently, only a small segment of FDI in developing countries reaches the agricultural sector. In Cambodia, 15 percent of authorized FDI benefits agriculture, in Mozambique the share is 9 percent, and in other countries it is even smaller: 4 percent in Ethiopia and less than 1 percent in Bangladesh (UNCTAD 2009). FDI flows to African agriculture are growing, however, and have tripled in the period from 1989-1991 to 2005-2007.

Although FDI in agriculture is not new, recent trends indicate increasing levels of resource-seeking investments (compared with past market-seeking investments). A significant fraction of the growth in FDI flows to Africa is spent on land acquisition. Figure 4 shows the amount of arable land allocated to investors between 2004 and early 2009 in five countries in Africa. Almost 80 percent of this amount is from foreign investors, except in Ethiopia, where 60 percent is owned domestically. It is often unclear, however, whether the land is leased or purchased, whether investments are installments or full payments, what fraction is spent on investments beyond land acquisition, and what proportion is accrued by smallholders. Although large-scale land deals have the potential to stimulate rural economic development by bringing in capital and technology, there are potential risks, including irreversible natural resource degradation; displacement of smallholder farmers by large, capital-intensive farms; and increasing domestic food insecurity due to rising food exports (Robertson and PinstrupAndersen 2010).

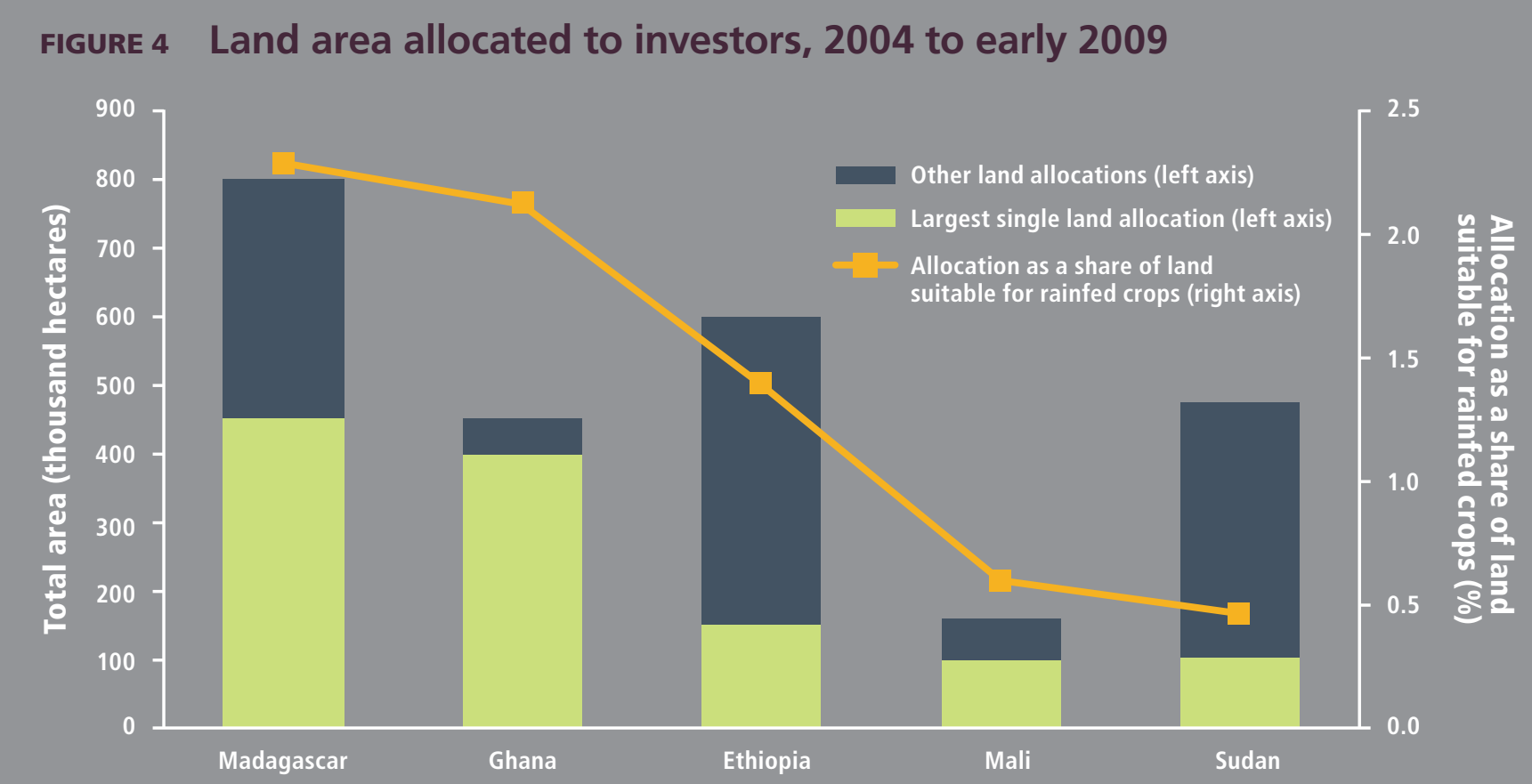




\section{Policy Options to Strengthen Smallholder Farmers with Agricultural Potential}

$\mathrm{T}$

HE VICIOUS CIRCLE OF VULNERABILITY, LOW-YIELDING ACTIVITIES, AND FOOD INSECURITY among smallholders needs to be broken. While many smallholder farmers can find moreprofitable livelihood opportunities outside of agriculture, other smallholders can be transformed into profitable businesses that operate at an efficient scale within agriculture. However, this group of potentially profitable smallholder farmers needs a policy environment that supports and nurtures this transformation and helps them overcome the challenges they face. This section focuses on a number of key (and often interlinked) interventions for potentially profitable smallholder farms described in Table 1 (page 4).

\section{PROMOTE CONTEXT-SPECIFIC FARM-SIZE POLICIES}

Given the heterogeneous character of economic growth and structures across developing countries, optimal farm size depends heavily on context, including the stage and structure of a country's economic and demographic development. Because well-functioning land sale and rental markets can have a major impact on agricultural productivity, governments in developing countries should not implement policies that promote cookie-cutter farm structures (for both rental and owner-occupied farms), which can lead to misallocation of resources. Demographic projections show that the rural and agricultural population in Africa-especially the rural youth - will continue to grow in absolute numbers for the next several decades, while these groups will soon decline in Asia (FAO 2012; van der Geest 2010). The resulting decline in farm size in Africa can be mitigated to some extent if policies and investments conducive to urban and nonfarm growth are adopted. But the reality is that increasingly smaller farms will be a major part of the agricultural landscape in the region for the next several decades. As a result, a greater emphasis needs to be placed on improving smallholders' productivity through stronger links to input and output markets; better access to rural infrastructure and agricultural services; access to capital and capacity building, especially among young people in agriculture; land policies that enable efficient smallholders to expand their operations by acquiring or renting land from less efficient neighbors who find other employment; and other business-friendly government policies (such as a sound legal and regulatory framework). A balance needs to be found between easing access to land among all farmers, including smallholders (especially the young), and largescale land acquisitions by foreign and domestic entities.

In many Asian countries, strong economic growth in nonfarm sectors and large-scale exit from agriculture and rural areas offer an opportunity to increase farm size. Economies with vibrant nonfarm sectors and declining agricultural populations (in absolute and relative terms) - for example, emerging economies such as China and Vietnam-are in need of institutions and policies that facilitate the growth of farm size and the movement of labor out of 
agriculture into other sectors. Short-term rental or longterm leasing arrangements facilitate labor mobility and transfer land to more productive users. Restrictions on rental transactions - such as ceilings on rental rates or prohibitions on absentee landownership—should be relaxed to enable rental markets to expand. Further, policies that identify legitimate owners play an especially critical role in on- and off-farm development by enabling the efficiencyenhancing transfer of land (through either rental or sale) to more productive users. For instance, evidence from China shows that documenting formal land rights has a positive impact on both farm productivity and nonfarm labor supply (Deininger and Jin 2005).

Similarly, social protection and improved access to housing, health services, and education for rural migrants and their families in urban centers will help them give up their land to farmers who stayed behind, allowing these farmers to increase the size of their farms. As labor becomes more expensive and moves out of agriculture in transforming and transformed economies, policies are needed to reorient the economies away from labor-intensive agricultural practices toward a more knowledge-based and mechanized agricultural model (, Yang, and Wang 2010). For example, the rising wage rate and ensuing labor shortage in China's agricultural sector are fueling a mechanization revolution. With the emergence of private mechanization service providers, machinery has replaced labor in land preparation and harvesting-activities that were previously labor intensive. The emergence of these service providers has been supported by pro-mechanization policies at the central and local levels, including subsidies for the purchase of agricultural machinery (Yang et al. 2013).

\section{ESTABLISH PRODUCTIVE SOCIAL SAFETY NETS}

Many smallholders will not be able to survive or transform themselves into profitable businesses in the agricultural sector. These farmers will need humanitarian assistance in the short run and viable exit strategies in long run. At the same time, many other smallholders have the potential to become profitable businesses with the support of targeted productive social-protection policies that offer opportunities for them to escape poverty, diversify their outputs, and cushion livelihood shocks such as the recent food price increase. Potentially profitable smallholder farmers in agriculture-based economies can benefit from the coupling of productivity-enhancing tools with social safety net support. This linkage could help smallholders augment their incomes and deal with shocks while they acquire the skills to undertake more productive activities. Interventions along these lines would include conditional cash transfers that are tied to household participation in primary schooling and health services, as seen in a number of Latin American countries.

Cross-sectoral social protection initiatives that support a broad collection of productivity-enhancing investments have shown promising results. For example, Ethiopia's Food Security Programme combines conditional and unconditional income transfers with products and services that promote agricultural productivity and microenterprise development, including credit, extension, and technology. The program has increased asset holdings and productivityenhancing investments among beneficiary households in rural areas (Gilligan, Hoddinott, and Seyoum 2009). It has also been credited with making many farmers and herders in Ethiopia more resilient to the drought-induced food security crisis that ravaged the Horn of Africa in 2011. Similarly, Bangladesh's Vulnerable Group Development Programme combines food security and nutrition interventions with income-generating activities that especially target women, increasing their per capita expenditure by a larger amount than the size of the transfer (Ahmed et al. 2009).

To enhance productivity, social protection initiatives could promote vocational training and other education schemes tailored to the technical needs of smallholder farmers and backed by national research and extension systems that promote smallholder-friendly and smallholder-accessible technologies. At the same time, such interventions could be used to help smallholders without profit potential increase their access to nutritious foods in the short term and acquire nonfarm skills and employment in the long term.

\section{IMPROVE RISK MITIGATION AND ADAPTATION STRATEGIES}

Farmers, and in particular smallholders, urgently need better access to risk-management tools and strategies to increase their resilience to myriad shocks, including price and weather. Such tools offer farmers added incentives to 
take productivity-enhancing risks such as adopting new technologies and switching to high-value crops. Insurance tools that could potentially help farmers manage risks range from basic weather and agricultural insurance to more sophisticated hedging options such as futures contracts and loan-guarantee funds. The International Finance Corporation (IFC) — the World Bank's private-sector arm-has developed the Agriculture Price Risk Management tool to extend access to hedging products among agricultural producers and consumers in developing countries to help shield them from price instability (IFC 2011a). Other innovative instruments include partial premium support (in conjunction with capacity-building efforts and regulatory reforms) and "insurance-for-work" schemes.

These initiatives are steps in the right direction, but more collaboration among private institutions, governments, and donors is needed to support research into the design of innovative, simple, and flexible insurance tools (such as group-based risk sharing and credit) that are adapted to the varying needs and constraints facing smallholders, especially targeting subsistence farmers with profit potential. The products need to be accompanied by investment in infrastructure (such as weather stations for weather-based indexes) and capacity building of farmers and providers. Most important, insurance schemes need to overcome the capital and credit constraints that limit smallholder demand for insurance, something that the current push for weather-based index insurance has been criticized for lacking (Binswanger-Mkhize 2012). To make insurance more affordable, "aggregators"- such as farmers' organizations, financial service providers, and input suppliers - could provide insurance and financial products as part of input contracts and vertical coordination mechanisms to help smallholders both manage risks and meet the demands of modern supply chains (Dries et al. 2009).

Reducing risks associated with price volatility requires supportive macroeconomic policies. National governments should encourage transparent, fair, and open global trade by eliminating formal and informal export restrictions and refraining from imposing new ones. Although export bans may help secure domestic food supplies, they tend to exacerbate global price hikes, thus hurting the poorest net buyers of food. Food prices have been increasingly linked to energy prices because of the growing diversion of food crops toward biofuel production as energy prices increase.
To minimize the negative impact that volatile energy (and hence food) prices have on farmers' incentives and performance, the competition between food and biofuel production should be minimized by limiting policies that promote the use of grain feedstock to produce biofuels. Such a shift would require more investment in developing either biofuel crops that grow on marginalized lands that are unsuitable for food crops or feedstocks that come from the non-edible parts of crops or from nonfood crops.

Policies that promote climate change mitigation and adaptation in agriculture are especially useful for helping smallholders manage risks while improving productivity. Investments in mitigation include helping farmers improve their energy efficiency and manage their land in ways that increase carbon storage. In fact, the global mitigation potential of agriculture has an estimated worth between US\$32 billion and US $\$ 420$ billion (Bryan et al. 2008). Investments in adaptation could focus on helping farmers adjust their planting dates as well as on developing and ensuring public provision of high-yielding crop varieties and technologies that are adapted to changing precipitation patterns and temperatures. The key is to prioritize investments and find the appropriate mix of flexible climate change mitigation and adaptation policies and tools with the highest productivityenhancing impact among different types of farmers, crops, and regions (Bryan et al. 2011).

At the same time, it is important to create policy incentives for smallholders to invest in mitigation and adaptation because many of the inputs and technologies required for low-carbon agricultural practices have high costs of production, purchase, and use. Brazil's Low-Carbon Agriculture Program, for example, provides financial incentives to encourage farmers to adopt crop and soil management activities that neutralize or minimize on-farm greenhouse gas emissions, including no-till farming, planting of commercial forests, and integrated crop-livestockforestry systems.

\section{LINK AGRICULTURE, NUTRITION, AND HEALTH}

A more integrated approach is needed to increase smallholders' productivity and improve their nutrition and health status. As both producers and consumers of more nutritious foods, smallholders have a potentially major role and stake in maximizing the linkages and synergies among 
agriculture, nutrition, and health. Investments to increase smallholder productivity should therefore be leveraged to improve nutrition and health in developing countries. Such investments could combine productivity-enhancing efforts with biofortification and biotechnology initiatives to breed nutritionally fortified varieties of staple food crops that are often grown by smallholder farmers and consumed by poor people in developing countries. Investments such as this can link agriculture to nutrition by creating economic value for producers and traders along with nutritional and health value for consumers. Experiences in Mozambique and Uganda with increasing the production, availability, and consumption of vitamin A-rich sweet potatoes are good examples of successful value-chain approaches (Hawkes and Ruel 2011). Countries should establish effective and transparent regulatory and monitoring systems to govern biotechnology and other emerging technologies so that producers and consumers can make timely and contextually relevant decisions about these technologies.

As smallholders become active participants in the food supply chain, their production activities increasingly have an impact on food safety and, at the same time, are affected by food safety standards. Safety regulations and monitoring systems need to be developed and implemented to ensure that agricultural intensification does not harm people's health, but regulations must be implemented in a way that does not alienate smallholders. Institutional innovations and cooperation - such as public-private partnerships, producer organizations, and group certification - are needed to help smallholders gain access to information, technologies, and training to satisfy food safety regulations, especially in transforming and transformed economies. Above all, more smallholder-specific research and evidence are needed on how to integrate the agricultural, nutrition, and health sectors in ways that have the most benefits for smallholders and on how to scale up successful innovations and initiatives.

\section{PROMOTE PRO-SMALLHOLDER VALUE CHAINS}

Linking smallholders to agrifood value chains is an important component of building smallholder resistance to shocks and improving their productivity and livelihoods. However, many smallholders in transforming and transformed economies are unable to participate in value chains because they cannot meet increasingly specific and strict quality standards, high volume requirements, and logistics specifications. For obvious reasons, companies tend to contract with larger farmers first and prefer farmers with certain nonland assets, such as irrigation or access to paved roads. These preferences act as barriers to smallholder participation in domestic (especially urban) and international markets. Overcoming these barriers requires institutional innovations for vertical and horizontal coordination among smallholders, including group lending, rural marketing cooperatives, and producer associations. These mechanisms will provide smallholder farmers with reduced transaction costs, improved access to market information, and increased bargaining power. However, such coordination mechanisms require strong institutional capacity and the active promotion of smallholder participation- not just membership - within these organizations to gain the maximum benefit for smallholders (Fischer and Qaim 2012). Similarly, information and communication technologies (ICTs) can offer smallholder farmers a wealth of opportunities to acquire real-time market information-on, for example, prices, demand, quality standards, and weather. With this information, farmers can make better-informed production and marketing decisions and participate more actively in value chains. Access to such technologies needs to be accompanied by efforts from the public and private sectors to improve both the information content of ICTs and the ability of potential users to employ these technologies.

A related concern within current agrifood supply chains is that roughly one-third of global food production is lost or wasted in the journey between farmers' fields and consumers' plates (Gustavsson et al. 2011). Most postharvest losses in developing countries occur before the farmgate (not at the consumer level, as is the case in developed countries) because of factors such as poor postharvest handling and storage that increase crop vulnerability to biodeterioration, pests, and unfavorable weather (Hodges, Buzby, and Bennett 2011). The dearth of postharvest capacity and infrastructure among smallholders and the subsequent loss of output significantly limit smallholders' profit potential, conservation of natural resources, and participation in high-value markets. In fact, evidence from Malawi shows that smallholder farmers who have access to postharvest storage technologies are more likely to adopt 
higher-value maize varieties, holding other farm-level characteristics constant (Ricker-Gilbert and Jones 2012). In response, public and private investments in agriculturebased and transforming economies should focus on reducing food loss along entire supply chains, from the development of crop varieties with better postharvest traits to better storage equipment and facilities that have low initial and recurring costs. Extension services should help smallholders build their postharvest crop management skills and maximize the benefits of postharvest technologies (Bokusheva et al. 2012). Policies in transformed countries should also place more emphasis on promoting consumer awareness of food waste.

\section{ENSURE SMALLHOLDER-FRIENDLY FINANCING AND INVESTMENT}

Moving from subsistence to more commercially oriented activities requires increased capital and investment flows that focus on smallholder farmers and their specific constraints and needs during times of both price stability and volatility. Increasing capital flows toward rural areas requires innovation in the channels and instruments through which financial services are offered to smallholders, including young people. The potential for novel approaches is wide and includes value-chain finance, rural leasing, loanguarantee funds, and ethical and Islamic banking. When it comes to smallholders, however, more research is needed to explore the viability and benefits of these innovative services before they can be scaled up. For example, loanguarantee funds under the Innovative Financing Program of the Alliance for a Green Revolution in Africa (AGRA) have been used to leverage much larger loans from commercial banks and have lowered interest rates for smallholders, but questions remain about whether this program has actually reached new customers who previously were unable to access such loans (Poulton and Macartney 2012). Increased efforts are needed to examine and promote ICTs, such as mobile phones and Internet kiosks, that can boost access to affordable payment, savings, and credit services for smallholders. Such financial products can be bundled with other development services, such as capacity-building and extension services.

The focus of financing efforts should also be shifted toward more medium- and long-term financing mechanisms to support commercially oriented capital investments by smallholders, such as machinery and storage facilities, which are critical for increasing productivity and modernizing smallholder agriculture. Areas that are worth exploring and test-piloting include the provision of long-term loans through producer organizations, development of financial leasing schemes, and the expansion of accepted collateral through the introduction of movable asset registries. ICTs can also be used to establish an electronic credit history for smallholders, thereby giving them a foundation for access to longer-term financing mechanisms (IFC 2011b). Above all, a vibrant rural financial system is needed that includes a diverse mix of financial institutions and networks that work together to support innovation and rural access among smallholders.

The public spending portfolio should also be strategically positioned to offer a short-term cushion for coping with livelihood shocks as well as long-term productivityenhancing or exit opportunities for smallholders to escape poverty and food insecurity. Public investments should be directed toward providing essential public goods that have the highest economic and social returns, including rural infrastructure (especially rural roads) and agricultural research and development. National research systems need to prioritize the development of location-specific and smallholder-friendly technological innovations across the whole agricultural value chain. A sound legal and regulatory environment is needed to maximize the private sector's contribution to smallholder productivity and to protect the property rights of smallholders and their surrounding natural resources. In conjunction, more research is needed to define appropriate instruments and strategies for integrating public-private partnerships and FDI into local economies. For example, regional and local governments could work with private businesses (foreign and domestic) to design and provide supportive services, including technological and organizational support, to smallholder farmers who serve as their suppliers (Jordaan 2011). The promotion of FDI from other developing and emerging countries also has the potential to generate greater spillover of more contextually appropriate technologies and skills to smallholders (UNCTAD 2012). Sound evidence-based research, information systems, and regulations at the national and global levels are needed to enhance the transparency of transactions and to understand the opportunities and threats for smallholders. 


\section{Conclusion}

World agriculture will need to undergo major changes if the demands of a growing and increasingly rich and urban population are to be met against a background of increasing scarcity of natural resources and other emerging challenges. Smallholders are an important part of the development equation. However, smallholders are not a homogeneous group, and development policies should not treat them as such. Instead the development pathways of smallholders consist of dynamic processes that vary according to the constraints they face and the stage of economic transformation. While some smallholder farmers have the potential to undertake profitable commercial activities in the agricultural sector, other farmers should be supported in exiting agriculture and seeking nonfarm employment opportunities. For smallholder farmers with profit potential, agriculture is risky in the face of climate change, price shocks, limited financing options, and inadequate access to healthy and nutritious food. Smallholders can successfully adapt their livelihood strategies to these challenges but need a supportive policy environment.

These policies and investments should focus on (1) promoting context-specific farm-size policies, (2) supporting productive social safety nets, (3) improving risk mitigation and adaptation strategies, (4) linking agriculture, nutrition, and health, (5) promoting pro-smallholder value chains, and (6) increasing smallholder-friendly financing and investment.

As with all public investments, the costs of investments and programs designed to improve smallholders' productivity need to be compared with the likely benefits in each country. Public funds have alternative uses, such as other investments within or outside agriculture. Moreover, in many circumstances, agricultural development requires addressing the obstacles faced by groups of agricultural producers other than smallholders.

This report has identified several areas in which further research could shed light on the opportunities for smallholder farmers with profit potential to move from subsistence to commercially oriented agricultural systems, as well as the challenges to their doing so. It is now time for governments in developed and developing countries, the research community, and private companies to focus their investments, innovations, and policies on helping these smallholders manage risk, improve their resilience to shocks, and increase their access to finance and capital while promoting future growth. All of these measures, adapted to each country's stage of economic development and transformation, will play a critical but varying role in bringing down barriers to profitable and efficient agricultural operations by smallholders. 


\section{REFERENCES}

Adamopoulos, T., and D. Restuccia. 2013. The Size Distribution of Farms and International Productivity Differences. Working Paper 480. Unpublished, Department of Economics, University of Toronto.

Ahmed, A., A. Quisumbing, M. Nasreen, J. Hoddinott, and E. Bryan. 2009. Comparing Food and Cash Transfers to the Ultra-Poor in Bangladesh. IFPRI Research Monograph 163. Washington, DC: International Food Policy Research Institute.

Aksoy, M., and A. Isik-Dikmelik. 2011. "Are Low Food Prices Pro-Poor? Net Food Buyers and Sellers in Low-Income Countries." In Food Prices and Rural Poverty, edited by M. Aksoy and B. Hoekman, 113-138. Washington, DC: World Bank.

Banerjee, A., and E. Duflo. 2007. “The Economic Lives of the Poor.” Journal of Economic Perspectives 21 (1): 141-167.

Barnett, A., and G. Rugalema. 2001. "HIV/AIDS." Brief 3 in Health and Nutrition: Emerging and Reemerging Issues in Developing Countries, edited by R. Flores and S. Gillespie. 2020 Vision Focus 5. Washington, DC: International Food Policy Research Institute.

Barrett, C., M. Bellemare, and J. Hou. 2010. "Reconsidering Conventional Explanations of the Inverse Productivity-Size Relationship." World Development 38 (1): 88-97.

Bateman, M. 2011. Microfinance as a Development and Poverty Reduction Policy: Is It Everything It's Cracked Up to Be? ODI Background Note. London: Overseas Development Institute.

Binswanger-Mkhize, H. P. 2012. "Is There Too Much Hype about Index-Based Agricultural Insurance?” Journal of Development Studies 48 (2): 187-200.

Bokusheva, R., R. Finger, M. Fischler, R. Berlin, Y. Marín, F. Pérez, and F. Paiz. 2012. "Factors Determining the Adoption and Impact of a Postharvest Storage Technology." Food Security 4 (2): 279-293.

Borja-Vega, C., and A. de la Fuente. 2013. Municipal Vulnerability to Climate Change and Climate-Related Events in Mexico. Policy Research Working Paper 6417. Washington, DC: World Bank.

Bryan, E., W. Akpalu, C. Ringler, and M. Yesuf. 2008. Global Carbon Markets: Are There Opportunities for Sub-Saharan Africa? IFPRI Discussion Paper 832. Washington, DC: International Food Policy Research Institute.

Bryan, E., C. Ringler, B. Okoba, J. Koo, M. Herrero, and S. Silvestri. 2011. Agricultural Management for Climate Change Adaptation, Greenhouse Gas Mitigation, and Agricultural Productivity: Insights from Kenya. IFPRI Discussion Paper 1098. Washington, DC: International Food Policy Research Institute.

Center for Global Prosperity-Hudson Institute. 2011. The Index of Global Philanthropy and Remittances 2011. Washington, DC: Hudson Institute. 
Chen, G., S. Rasmussen, and X. Reille. 2010. Growth and Vulnerabilities in Microfinance. Focus Note 61. Washington, DC: Consultative Group to Assist the Poor.

Cotula, L., S. Vermeulen, R. Leonard, and J. Keeley. 2009. Land Grab or Development Opportunity? Agricultural Investment and International Land Deals in Africa. London: International Institute for Environment and Development; Rome: Food and Agriculture Organization of the United Nations and International Fund for Agricultural Development.

Deininger, K., and S. Jin. 2005. "The Potential of Land Rental Markets in the Process of Economic Development: Evidence from China." Journal of Development Economics 78 (1): 241-270.

Deininger, K., S. Jin, and H. Nagarajan. 2008. "Efficiency and Equity Impacts of Rural Land Rental Restrictions: Evidence from India." European Economic Review 52 (5): 892-918.

de Janvry, A., and E. Sadoulet. 2009. "Agricultural Growth and Poverty Reduction: Additional Evidence." World Bank Research Observer 25 (1): 1-20.

Dercon, S. 2009. "Risk, Poverty, and Insurance." Brief 3 in Innovations in Insuring the Poor, edited by R. Vargas Hill and M. Torero. 2020 Vision Focus 17. Washington, DC: International Food Policy Research Institute.

Dewen, W. 2010. Can Social Security Boost Domestic Consumption in the People's Republic of China? ADBI Working Paper 215. Tokyo: Asian Development Bank Institute.

Dries, L., E. Germenji, N. Noev, and J. Swinnen. 2009. "Farmers, Vertical Coordination, and the Restructuring of Dairy Supply Chains in Central and Eastern Europe." World Development 37 (11): 1742-1758.

Fan, S., and C. Chan-Kang. 2003. "Is Small Beautiful? Farm Size, Productivity, and Poverty in Asian Agriculture." Plenary paper prepared for the 25th International Conference of Agricultural Economists, July 17, Durban, South Africa.

Fan, S., and R. Pandya-Lorch, ed. 2012. Reshaping Agriculture for Nutrition and Health. Washington, DC: International Food Policy Research Institute.

FAO (Food and Agriculture Organization of the United Nations). 2000. 2000 World Census of Agriculture. Rome.

_ 2010. 2010 World Census of Agriculture. Rome.

-2011. Save and Grow: A Policymaker's Guide to the Sustainable Intensification of Smallholder Crop Production. Rome.

- 2012. FAOSTAT database. Accessed July 26, 2012. http://faostat.fao.org.

Fischer, E., and M. Qaim. 2012. "Linking Smallholders to Markets: Determinants and Impacts of Farmer Collective Action in Kenya." World Development 40 (6): 1255-1268. 
Gilligan, D., J. Hoddinott, and M. Seyoum. 2009. "An Analysis of Ethiopia's Productive Safety Net Programme and Its Linkages." Journal of Development Studies 45 (10): 1684-1706.

Gustavsson, J., C. Cederberg, U. Sonesson, R. van Otterdijk, and A. Meybeck. 2011. Global Food Losses and Food Waste: Extent, Causes, and Prevention. Rome: Food and Agriculture Organization of the United Nations.

Hainmueller, J., M. Hiscox, and M. Tampe. 2011. Sustainable Development for Cocoa Farmers in Ghana: Baseline Survey: Preliminary Report. Cambridge, MA: Massachusetts Institute of Technology and Harvard University.

Hawkes, C., and M. Ruel. 2011. Value Chains for Nutrition. 2020 Conference Paper 4. Washington, DC: International Food Policy Research Institute.

Hazell, P. 2009. “Transforming Agriculture: The Green Revolution in Asia.” In Millions Fed: Proven Successes in Agricultural Development, edited by D. Spielman and R. Pandya-Lorch, 25-32. Washington, DC: International Food Policy Research Institute.

Hazell, P., C. Poulton, S. Wiggins, and A. Dorward. 2007. The Future of Small Farms for Poverty Reduction and Growth. 2020 Discussion Paper 42. Washington, DC: International Food Policy Research Institute.

- 2010. "The Future of Small Farms: Trajectories and Policy Priorities." World Development 38 (10): 1349-1361.

Helfand, S., and E. Levine. 2004. "Farm Size and the Determinants of Productive Efficiency in the Brazilian Centre-West." Agricultural Economics 31 (2-3): 241-249.

Heltberg, R. 1998. "Rural Market Imperfections and the Farm Size-Productivity Relationship: Evidence from Pakistan.” World Development 26 (10): 1807-1826.

Hodges, R., J. Buzby, and B. Bennett. 2011. "Postharvest Losses and Waste in Developed and Less-Developed Countries: Opportunities to Improve Resource Use." Journal of Agricultural Science 149 (S1): 37-45.

Horioka, C., and J. Wan. 2007. "The Determinants of Household Saving in China: A Dynamic Panel Analysis of Provincial Data." Journal of Money, Credit, and Banking 39 (8): 2077-2096.

IFC (International Finance Corporation). 2011a. IFC Annual Report 2011. Washington, DC.

- 2011b. Scaling Up Access to Finance for Agricultural SMES: Policy Review and Recommendations. Washington, DC.

IFPRI (International Food Policy Research Institute). 2005. The Future of Small Farms: Proceedings of a Research Workshop, Wye, UK, June 26-29, 2005. Washington, DC.

Jordaan, J. 2011. "FDI, Local Sourcing, and Supportive Linkages with Domestic Suppliers: The Case of Monterrey, Mexico." World Development 39 (4): 620-632. 
Karfakis, P., J. Velazco, E. Moreno, and K. Covarrubias. 2011. Impact of Increasing Prices of Agricultural Commodities on Poverty. Agricultural Development Economics Division (ESA) Working Paper 11-14. Rome: Food and Agriculture Organization of the United Nations.

Lobell, D., W. Schlenker, and J. Costa-Roberts. 2011. "Climate Trends and Global Crop Production since 1980.” Science 333 (6042): 616-620.

Minot, N., and R. Dewina. 2013. Impact of Food Price Changes on Household Welfare in Ghana. IFPRI Discussion Paper 1245. Washington, DC: International Food Policy Research Institute.

Motes, W. 2011. Global Food and Agriculture Productivity: The Investment Challenge. Washington, DC: Global Harvest Initiative.

Nelson, G., M. W. Rosegrant, A. Palazzo, I. Gray, C. Ingersoll, R. Robertson, S. Tokgoz, T. Zhu, T. Sulser, C. Ringler, S. Msangi, and L. You. 2010. Food Security, Farming, and Climate Change to 2050: Scenarios, Results, Policy Options. Washington, DC: International Food Policy Research Institute.

Nose, M., and F. Yamauchi. 2012. Long-Term Impacts of Global Food Crisis on Production Decisions: Evidence from Farm Investments in Indonesia. Policy Research Working Paper 6065. Washington, DC: World Bank.

Obayelu, O. A. 2012. "Saving Behavior of Rural Households in Kwara State, Nigeria." African Journal of Basic and Applied Sciences 4 (4): 115-123.

Omamo, S., X. Diao, S. Wood, J. Chamberlin, L. You, S. Benin, U. Wood-Sichra, and A. Tatwangire. 2006. Strategic Priorities for Agricultural Development in Eastern and Central Africa. Research Report 150. Washington, DC: International Food Policy Research Institute.

Pauw, K., J. Thurlow, and D. van Seventer. 2010. Droughts and Floods in Malawi: Assessing the Economywide Effects. IFPRI Discussion Paper 962. Washington, DC: International Food Policy Research Institute.

Pei, X., A. Tandon, A. Alldrick, L. Giorgi, W. Huang, and R. Yang. 2011. "The China Melamine Milk Scandal and Its Implications for Food Safety Regulation.” Food Policy 36 (3): 412-420.

Poulton, C., and J. Macartney. 2012. "Can Public-Private Partnerships Leverage Private Investment in Agricultural Value Chains in Africa? A Preliminary Review.” World Development 40 (1): 96-109.

Poulton, C., A. Dorward, and J. Kydd. 2010. “The Future of Small Farms: New Directions for Services, Institutions, and Intermediation.” World Development 38 (10): 1413-1428.

Reardon, T., C. Barrett, J. Berdegué, and J. F. Swinnen. 2009. "Agrifood Industry Transformation and Small Farmers in Developing Countries." World Development 37 (11): 1717-1727. 
Ricker-Gilbert, R., and M. Jones. 2012. "Does Access to Storage Protectant Increase Smallholder Adoption of Improved Maize Seed? Insights from Malawi." Paper presented at the 2012 Agricultural and Applied Economics Association Annual Meeting, Seattle, WA, US, August 12-14.

Robertson, B., and P. Pinstrup-Andersen. 2010. "Global Land Acquisition: Neo-Colonialism or Development Opportunity?” Food Security 2 (3): 271-283.

Schicks, J., and R. Rosenberg. 2011. Too Much Microcredit? A Survey of the Evidence on Overindebtedness. Occasional Paper 19. Washington, DC: Consultative Group to Assist the Poor.

Timmer, C. P. 1988. “The Agricultural Transformation.” In Handbook of Development Economics. Vol. 1, edited by H. B. Chenery and T. N. Srinivasan, 275-332. Amsterdam: North-Holland.

Ulimwengu, J., S. Liverpool-Tasie, J. Randriamamonjy, and R. Ramadan. 2011. Understanding the Linkage between Agricultural Productivity and Nutrient Consumption: Evidence from Uganda. IFPRI Discussion Paper 1128. Washington, DC: International Food Policy Research Institute.

UN (United Nations). 2004. The Impact of AIDS. New York: UN Department of Economic and Social Affairs-Population Division.

UNCTAD (United Nations Conference on Trade and Development). 2009. World Investment Report 2009: Transnational Corporations, Agricultural Production, and Development. New York.

- 2012. Technology and Innovation Report 2012: Innovation, Technology, and South-South Collaboration. New York: United Nations.

van der Geest, K. 2010. Rural Youth Employment in Developing Countries: A Global View. Rome: Food and Agriculture Organization of the United Nations.

Welch, R. M., and R. D. Graham. 1999. "A New Paradigm for World Agriculture: Meeting Human Needs: Productive, Sustainable, Nutritious.” Field Crops Research 60 (1/2): $1-10$.

Wheeler, D. 2011. Quantifying Vulnerability to Climate Change: Implications for Adaptation. CGD Working Paper 240. Washington, DC: Center for Global Development.

World Bank. 2008. World Development Report 2008: Agriculture for Development. Washington, DC.

Yang, J., Z. Huang, X. Zhang, and T. Reardon. 2013. "The Rapid Rise of Cross-Regional Agricultural Mechanization Services in China.” American Journal of Agricultural Economics, forthcoming.

Zhang, X., J. Yang, and S. Wang. 2010. China Has Reached the Lewis Turning Point. IFPRI Discussion Paper 977. Washington, DC: International Food Policy Research Institute. 


\section{ABOUT THE AUTHORS}

Shenggen Fan is director general of the International Food Policy Research Institute, Washington, DC.

Joanna Brzeska is a consultant researcher at the International Food Policy Research Institute, Washington, DC.

Michiel Keyzer is a professor of economics at the Vrije Universiteit and director of the Centre for World Food Studies of the Vrije Universiteit (SOW-VU), Amsterdam, the Netherlands.

Alex Halsema is a researcher at the Centre for World Food Studies of the Vrije Universiteit, (SOW-VU), Amsterdam, the Netherlands. 
I SBN $978-0-89629-558-2$

.

INTERNATIONAL FOOD POLICY RESEARCH INSTITUTE

\author{
A member of the CGIAR Consortium | A world free of hunger and malnutrition
}

